\title{
노…
}

\author{
レーザー・光による生体観測と診断小特集に寄せて \\ 會沢 勝夫 \\ 東京医科大学生理学第二講座（广 160 東京都新宿区新宿 6-1-1）
}

\section{Topical Papers on \\ Optical Monitoring and Diagnotics for Biomedical Applications}

\author{
Katsuo AIZAWA \\ Department of Physiology, Tokyo Medical College, 6-1-1 Shinjuku Shinjuku-ku Tokyo 160
}

(Received January 14, 1997)

可視から赤外光を中心とした電磁波領域での生体観測 技術は最近急速に展開し始めている。これはレーザー技 術の発展に多分に依存している。 今回, レーザー・光によ る生体観測と診断について小特集としてとりあげてみ た。

生体自体は光エネルギーに依存して存在し,多種多様の 反応を介してその営みを行っている。この機能を行う際 に余分なエネルギーは熱として放出して体温の維持(機能 を行う最適環境を保つため)に努めている。同時に，それぞ れ特有の波長を放出して生体構成分子は安定な基底状態 に戻っていく.

一般に, 種々の機能は必要最小限のエネルギーを取り入 れて有効に活用しているため体外にまで光を放出できな い.しかし, 人為的に多分のエネルギ一を供給すると機能 を構成する物質特有の光の吸収状態や光放出状態を観測 できる。これらの観測を介して生体構成物質の存在量を 把握する事ができる。

生体構成物質のテトラピロール環はピロール環が4 個で リングを形成している分子である。生体の中では植物の クロロフィルや動物のへモグロビン, チトクローム酵素等 の分子構造の骨格を担っている。これら分子の基本的な 機能はクロロフィルでは青と赤 $(450 \mathrm{~nm}, 650 \mathrm{~nm})$ の光を吸

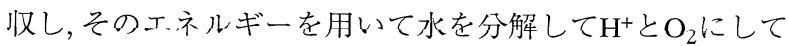
いる．血液中の赤血球内に存在するへモグロビンでは $\mathrm{O}_{2}$ の運搬に関与し細胞内呼吸に必要な $\mathrm{O}_{2}$ を供給している。 細胞内のミトコンドリアの内膜に存在しているチトク ローム酵素では物質代謝により産生した $\mathrm{H}^{+}$を $\mathrm{O}_{2}$ と結合さ せ水にすると同時に生体の熱源であるATPをチトクローム 酵素の酸化に伴うエネルギーを利用して産生している。 この様に,テトラピロール環は光エネルギーや分子結合エ ネルギーを介して生体内に存在する酸素との反応に関与
している.

人の体に㧍いてへモグロビンは種々の組織内で行われ ている呼吸に欠かせない酸素を供給するキャリヤーとし て大切な機能を持っている.このへモグロビンの分光的 特徵を用いて血管内の動態の画像解析により病態が把握 出来るようになってきた。

20世紀の初頭に癌組織内にへモグロビンの分産物が集 積する現象が観測された。 以後, 癌組織に集積する光感受 性物質の研究が進められてきた。

光感受性物質フォトフリン (ポルフィリン分子)を初期 癌の患者に静脈投与した後にこの吸収波長で癌部位を レーザー照射する治療法が厚生省より1994年10月に認可 された。

この治療機構は光感受性物質がレーザーを吸収する事 により二次的に産生される活性酸素の強い酸化作用によ る癌細胞の崩壊によって説明できる。

この様に,レーザー癌治療は光感受性物質の吸収波長の 励起によるため, 励起波長が生体構成分子(へモグロビン 等)の吸収帯と同じ場合には効果を減少させる. そこで, 光 感受性物質をへム構造から葉緑素のクロリン構造に変え へモグロビンよりも長波長に大きな吸収带を持つ波長 (664nm) で励起して治療効果を増大させる事ができた。同 時にここの光感受性物質の波長 $670 \mathrm{~nm}$ にピークを持つ蛍光 スペクトル及び画像を観測でき, 癌の存在部位が明確に確 認出来るようになった，又，この光感受性物質により涿状 動脈硬化部位の観測も可能になってきた.

この様に, 可視から赤外波長領域に扔けるレーザーを用 いての分光学的手段により病態部位の状況が観測できる ように成ってきた。これから先も,より情報量の多い観測 手段が開発され病態解析のために有効なデーターを提供 していくと思われる. 